\title{
Preliminary Phytochemical Screening and Antibacterial Activity on Stem Bark Extracts of Ceiba Pentandra
}

\author{
*Ezigbo V.O., Odinma, S.C., Duruaku, I.J. and Onyema, C.T. \\ "Department of pure and Industrial Chemistry Anambra State University Uli. Nigeria \\ Department of Pure and Industrial Chemistry, Nnamdi Azikiwe University Awka, Nigeria.
}

\begin{abstract}
Ceiba Petandra is widely used in complementary medicine. Its stem bark extracts obtained via soxhlet extraction using n-hexane, acetone and ethanol gare alkaloids, Steroids, Saponins, Cardiac glycosides, triterpenes and tannins when screened phytochemically. These extracts were further investigated for their antibacterial activity against staphylococcus aureus klebsiella, pneumoniae and pseudomonas aeruginosa with ampicillina, as standard. Highest anti- bacterial activity with acetone extract at a concentration of $300 \mathrm{mg} / \mathrm{ml}$ and least activity with ethanol extract at a concentration of $100 \mathrm{mg} / \mathrm{ml}$. $n$ - Hexane extract showed no inhibition on the tested micro-organisms.
\end{abstract}

Key Words: Ceibs petandra, anti-bacterial activity, extracts, stem bark, phytochemical screening.

\section{Introduction}

Ceiba Petandra is very popular in African Trade-medicine. The Igbos call it Akpu Ogwu, Hausa: giyayya tamata $[1,2,3]$. Different parts of the plant are used in treatment fever, cough, gastro-intestinal complaints, itching, syphilitic ulcer, inflammation of the eyes, diarrhea, colic, intestinal worms, Ophtalmia and for application to wounds. The plant is known to have other various therapeutic applications depending on the areas and tradition there in prevailing $[1,4]$. These applications include anthelminthic activity, antidote activity and activity against chickenpox, Vertigo, Syncope, conjunctivitis and venereal diseases [5]. A detailed description of the plant is given by Keay [2]. Traditional and folklore medicine plays an important role in health care services around the globe. Plants are known to synthesize a wide range of chemical substances, many of which have been and can be of tremendous value in treatment and prevention of diseases. Man has depended on plants and plant extracts as a source of medicine, food, shelter, clothing etcetera, since creation [6]. The efficacy of most plants in treatment of ailments has encouraged research into these areas and today plants alone offer a host of analgesics, antibiotics, heart drugs, enzymes, hormones, diuretics, anti-parasitic compounds, ulcer treatments, dentifrices, laxatives, dysentery treatments, and anti- coagulants among others [7]. Owing to its trado-medical importance, this study investigates the crude stem bark extracts of ceiba pctandra in order determine its phytochemical compounds responsible for reported therapeutic activities. Antimicrobial activity of the extracts was studied to establish a scientific basis for its activity against bacterial related ailments.

\section{1}

\section{Material And Methods}

\section{SAMPLING AND SAMPLE PREPARATION.}

Stem bark of Ceiba petandra was collected using a cutlass on the campus of Anambra State University. It was identified by Mr. Onuchukwu, C.A. a retired forestry Officer of Ihiala Zone Anambra State Nigeria. Fresh stem bark was dried under shade for three weeks, and than pulverized with a mortar and pestle. The fine powdered sample was stored in a polyethylene bag until needed for analysis.

2.2 EXTRACTION: 100g of pulverized stem bark was introduced into a soxhlet extractor using $\mathrm{n}$ - hexane as solvent [8]. Plant material (stem bark) was exhaustively extracted, collected and allowed to evaporate to dryness at room temperature. This procedure was repeated with acetone and ethanol respectively, as extraction solvents, successively. Crude extracts obtained were labelled as HCF, ACF, and ECF for n- hexane, acetone, and ethanol extracts, respectively.

2.3 PHYTOCHEMICAL SCREENING: The crude extracts were evaluated for the presence of saponins, tannins, flavonoids, steroids, glycosides, alkaloids and terpenes, using standard procedures $[8,9,10]$.

2.4 ANTIBACTERIAL ASSAY: The crude extracts were screened for anti-microbial activity using the disk diffusion method $[11,12]$. The nutrient agar was used as growth medium for the microbes. Preparation of nutrient agar medium was by $5 \mathrm{~g}$ of agar in $250 \mathrm{ml}$ of distilled water in a flask. This was sterilized in an autoclave at $121^{\circ} \mathrm{c}$ for $15 \mathrm{~min}$, cooled and transferred into sterile Petri-dishes to solidify. 
Culture of Staphylococcus aureus, klebsiella Pneumoniae and Pseudomonas aeruginosa were obtained from the Biological Science Department Anambra State University, Uli. The isolates were separately cultured over each nutrient agar plate in a zig-zag streaking manner. Solutions of varying concentrations were prepared for each extract, using pure extruding solvent used in their respective extractions. The solutions were used for measurement of anti-bacterial activity of various extracts by paper disc method. The papers were cut into small disc and introduced into each beaker, containing the diluted extracts. The soaked papers disc were then placed on the plates and incubated for $24 \mathrm{hrs}$ at $37^{\circ} \mathrm{c}$. At the elapse of $24 \mathrm{hrs}$, plates were measured for clear zones of activity. Zones of inhibition were measured and their values recorded. Same test was repeated with ampicillin, vended antibiotic, using same concentrations as the extracts, and its bioactivity compared with that of extracts. These experiences were done in duplicates and average zones of inhibition recorded (in $\mathrm{mm}$ ).

\section{Results And Discussion}

The results of weight of solute extracted from $100 \mathrm{~g}$ of powdered stem bark sample using $\mathrm{n}$ - hexane, acetone and ethanol respectively, is given in Table1. Result of preliminary qualitative phytochemical analysis of the extracts is shown in Table 2

Table 1: Characteristics, Nature yield of Extracts

\begin{tabular}{|l|l|l|l|l|}
\hline Solvent & Extracts code & Nature colour & Yields(g) & Yield \% \\
\hline n-Hexane & HCF & Yellow solid & 1.083 & 1.10 \\
\hline Acetone & ACF & Brown solid & 3.139 & 3.14 \\
\hline Ethanol & ECF & Brown paste & 10.257 & 10.30 \\
\hline
\end{tabular}

Table 2: Physiochemical composition of Extracts of Ceiba petandra

\begin{tabular}{|l|l|l|l|l|l|l|l|}
\hline Extracts & Flavonoids & Steroids & Tannins & Saponins & Cardias glycosides & Alkaloids & Triterpenes \\
\hline n- HEXANE & $* * *$ & $* * *$ & $\sqrt{ } \sqrt{ }$ & $* * *$ & $\sqrt{\sqrt{ }}$ & $* * *$ & $* * *$ \\
\hline Acetone & $\sqrt{\sqrt{ }}$ & $\sqrt{\sqrt{ }}$ & $* * *$ & $\sqrt{ } \sqrt{ }$ & $* * *$ & $* * *$ & $\sqrt{ } \sqrt{ }$ \\
\hline Ethanol & $* * *$ & $* * *$ & $* * *$ & $\sqrt{\sqrt{ }}$ & $* * *$ & $* * *$ \\
\hline
\end{tabular}

$\sqrt{\sqrt{ }}=$ Present $; \quad * * *=$ Absent

Phytochemical analysis of ceiba petandra revealed presence of flavonoids, Saponins, steroids and triterpenes in acetone extract, saponins in ethanol extract. The non-polar hexane extracts contained only tannins and cardic glycosides (Table 2). These phytochemical compound perhaps are responsible for the significant role in the vitro antibacterial activity of this plant [13]. Antibacterial activity (average zones of inhibition, mm) of the various extracts of Ceiba petandra are reported in Table 3.

Table 3: Average Zone of Inhibition (in $\mathrm{mm}$ ) of bacterial growth of stem bark extracts of Ceiba petandra and Ampicilliin

\begin{tabular}{|c|c|c|c|c|c|}
\hline Test Organism & Conc./(mg/g) & ECF & $\mathrm{ACF}$ & $\mathrm{HCF}$ & Ampicillin \\
\hline \multirow{3}{*}{$\begin{array}{l}\text { Staphylococcus } \\
\text { auerus }\end{array}$} & 300 & $+(3.0)$ & $+(5.0)$ & & +2.0 \\
\hline & 200 & $+(1.0)$ & $+(2.0)$ & & $+(1.0)$ \\
\hline & 100 & & + & & $1+1.0$ \\
\hline \multirow{3}{*}{$\begin{array}{l}\text { pseudomonas } \\
\text { Aeruginosa }\end{array}$} & 300 & & $+(6.0)$ & & $+(8.0)$ \\
\hline & 200 & & $+(5.0)$ & & $+(6.0)$ \\
\hline & 100 & & +1.0 & & +5.0 \\
\hline \multirow{3}{*}{$\begin{array}{l}\text { Kiebsiella } \\
\text { Pnumoniae }\end{array}$} & 300 & $+(3.0)$ & $+(7.0)$ & & $+(6.0)$ \\
\hline & 200 & $+(2.0)$ & $+(5.0)$ & & $+(2.0)$ \\
\hline & 100 & $+(1.0)$ & $+(3.0)$ & & $+(1.0)$ \\
\hline
\end{tabular}

$+=$ Activity; $\quad-=$ Inactivity

Several researchers have reported on the medicinal properties of plants derived compounds. These classes of compounds are known to show curative activity against several bacterial and it is not surprising that these plants extracts are used traditionally by herbalist to cure bacteria related ill-health. For instance, saponins are reported to be effective in the treatment of syphilis, rheumatism and certain skin disease: treatment of abscesses and other swellings, ulcer and septic wounds [14]; management of inflammation [13]. Saponins are responsible for tonic and stimulating activities observed in Chinese and Japanese Medical herbs [15]. Flavonoids which are part of the phytochemical constituents of Ceiba petandra are known to have hypoglycemic activity used in the treatment of diabetes [16], exhibit anti-inflammatory, anti-angionic, anti-allergic effect, analgesic and antioxidant properties[17,18]; enzymes inhibitors, vascular, oestrogenic, cytotoxic antitumor, antispamolytic and antidiarhoetic activities, antidysentry and infectious diseases, hepatoprotective and anti-fungal agents[18]. Flavonoids are known to exhibit a wide range of biological activities one of which is either ability to scavenge for hydroxyl radicals and superoxide anions radicals and thus health promoting in action. Also the diuretic antibacterial $[9,19]$ and antifungal antiplasmodial and anti-mycobacterial activities $[10,20]$, cytotoxic and 
antiprotozoal activity [21] of flavonoids containing plants have been reported. The combination of saponins and steroids is known to show curative activity against several pathogens [22]. Similarly, [23] has also observed the presence of such constituents, as flavonoids and saponins, flavonoids and terpenoids[24], saponins, flavonoids, and steroids [15]. These have shown to exhibit varying antimicrobial activities [22]. Terpenoids are said to have some biological activities in animals including man and also play a meaningful role in human medicine. They are reported to have a wide spectrum of biological activities including bactericidal, fungicidal, antiviral, cytotoxic, analgesic, anticancer, spermicidal, cardiovascular and antiallergic [25]. A vast number of terpenoid have been evaluated as potential anti-inflammatory molecules not only in invitro animal models, but also in well defined ex vivo cultures [26]. The biological activity of the acetone extract of Ceiba petandra can be attributed to the synergistic effect of the combination of flavonoids, steroids, terpinoids and saponins. The synergistic antibacterial effects of flavonoids, saponins, terpenes and steroids have been reported [27], [16].

\section{Conclusion:}

The results obtained in this study thus suggests that the identified phytochemicals may be the bioactive constituents responsible for the efficacy of stem bark of caiba petandra against fever, syphilitic, ulcer, inflammatory disease wounds, conjunctivitis etc. Based on this, it suggested that the traditional medicinal use of Cieba petrandra be continued and scientific evaluation of its active constituents given serious attention. The acetone extract of Ceiba patandra was found to show a higher inhibitory activity than ampicillin with respect to the tested microorganisms. The variation in the observed antibacterial activity of different plant extract and ampicillin could be explained in terms of difference in polarity of solvents used and possible compound they could extract, as well as their ability to dissolve or diffuse in the media used in the assay.

\section{References:}

[1]. World Agroforestry (2008). crossopyer x febrifuga Benth. w.w.w.Worldagroforestry.org/sea/products

[2]. R.W.J. Keay (1989). Trees of Nigeria. Clarendon press Oxford, pp 425-426.

[3]. E.c. Agishi (2004). Etulo, Idoma, Tiv and Hausa names of plants . Agitab publishers Ltd, Markudi. pp.42 and 102

[4]. L.S Gill (1992) Ethnomedical uses of plants in Nigeria. Uniben press, University of Benin, Benin City. pp 86-87

[5]. P. Forest, O. Ghirardi, B. Gabetta and A. Cristoni (1989). Triterpene Saponins having anti- inflammatory, macolytic and antiedetic activities, process for the preparation thereof and pharmaceutical compositions containing them. United State Patent 4879376.

[6]. T.A. Tor- Anyiin, R. Sha'ato, and H.O.A. Oluma (2006). Phytochemical screening and Antibacterial activity of Cissaplelos mucronata A. Rich (Menispermaceae) extract. J. Pharm. and Bioresources 3(2): 103-106.

[7]. H.G. Barker (1978). Plant and civilization. $3^{\text {rd }}$ ED Wadsworth publishing company, Inc. Californa Pp 86.

[8]. J.B Harborne (1984). Phytochemical methods. A guide to modern techniques of plant analysis. $2^{\text {nd }}$ Ed. Chapman and Hall, New York. Pg. 5, 120, 196-197.

[9]. I.J Alinnor (2007). Prelimary phytochemical and antibacterial activity screening of seeds of Garcinia cola J.Chem. Soc. Nigeria 32(2): 4147.

[10]. C.E Ogukwe, E.E. Oguzie, C. Unaegbu a nd B.N. Okolue (2004). Phytochemical screening of the leaves of Sansevieria trifasciata J.Chem. Soc. Nigeria, 29 (1): 8-10.

[11]. H.C Ericson, G. Tunerall, and K. Wickman (1960). The paper disc method for determination of bacterial sensitivity to antibiotic. Scand. J Clin. Lab Invest., 12:414-146.

[12]. A.W Bauer,W.M.M.Kirby, J.C. Sherris, and M. Turck (1966). Antibiotic Susceptibility resting by a standard ized single disc method. Amer. J. Clincal Path, 45:493-496.

[13]. M.F Adebgoye D.A Akinpelu, A.L Okoli (2008). The bioactive and phytochemical properties of G. Kola (Heckel) seeds extracts on some pathogens. Afr. J. Biotechnology 7(21): 3938-3988.

[14]. I.Y. Chindo, K.A. Yongabi, M.O. Agbo and Z.B. Timothy (2002). Extract of Agerantum conyzoids. Pesticidal activity and phytochemical studies. J. Chem. soc. Nigeria, 27(2): 110-113.

[15]. I.J Alinor (2008) preliminary phytochemical and antibacterial activity screening of leaves of Varnonia amygdalina J. Chem. Soc. Nigeria 33(1): 172-177.

[16]. P.E Ghamba, E.B. Agbo, A.F. Umar, D.N. Bukbuk, L.J. Goje (2012). In vitro antibacterial activity of extracts of crude ethanol, acetone, and acqueous Garcinia Kola seeds extracts on selected clinical isolates. Afr. J.Biotechology 11(6):1478-1483.

[17]. P. Hodek, P. Trefil, A.Stiborova (2002). Flavonoids potent and versatile biologically active components interacting with Cytochrome Pp. 450. Chemico- biological interaction, 139: 1-21.

[18]. J.B. Harbone, C.A. Williams (2000). Advances in flavonoid research since 1992. Phytochemistry 55:481-504.

[19]. G.L. Penecilla, C.P. Magno (2011). Antibacterial activity of extracts of twelve common medicinal plants from Philippines. J. Med. Plants Research 5(16): 3975-3981.

[20]. V. Yenjai, K. Prasanphen ,S. Daodee, V. Wongpanich, P. Kittakoop (2004). Bioactive flavonoids from Kaemferia Parviflora Fitoterapia 75:89-92

[21]. R. Borges- Argaez, L. Balnbury, A. Flowers, A Gimenez-Turba, G. Riuz, P.G. Waterman, L.M. Pena- Rodriguez (2007). Cytotoxic and antiprotozoal activity of flavonoids from Lonchocarpus spp. Phytomedicine 14:530-533.

[22]. J. P atocka (2003). Biologically active Pentacyclic triterpenes and their current medicine signification. J. Applied Biomedicine 1:7-12.

[23]. B. Heras, B.Rodriuez, L. Bosca, A.M. Villar(2003). Terpenoids: sources, structure elucidation and therapeutic potential in inflammation. Current Topics in Medicinal Chemistry, Bet ham Science Publishers Ltd. 3: 171-185.

[24]. M.M. Hassan, A.O. Oyewale. J.O. Amupitan, M.S. Abdulahi, and E.M. Okonkwo (2004). Preliminary Phytochemical and antibacterial investigation of extracts of the roots bark of detarium microcapum. J.Chem Soc. Nigeria 29(1): 26-29.

[25]. E.A. Sofowora (1974). Medicinal plants and traditional medicine in Africa ( $1^{\text {st }}$ Ed.). John Wiley and sons, New York, pp. 256.

[26]. S. Jeeva, M. Johnsons, J.S. Aparna, V. Irudayaraj (2011). Preliminary Phytochemical and anti-bacterial studies on flowers of selected medicinal plants. Int. J. Med. Arom. Plants 1(2): 107-114.

[27]. E. Tella, D. Djamen, D.R. Djoude, L. Tatsadjeu, D.Tantoh, J.T. Mbafor, Z.T. Fomum (2002). Antimicrobial activity of Bridelia ferriginea. Fitoterapia 73:343-345.

[28]. O. Timothy, M. Idu (2011) Preliminary Phytochemical and in Vitro anti microbial properties of aqueous and methanol extracts of lcacina trichantha Oliv. Leaf. Int. J. Med. Arom. Plants. 1(3): 184-188. 